\title{
Vitamin C Antioxidant Effect on Gamma - Glutamyl Transferase (Ggt) Activity in Rats under Paraquat Toxicity.
}

\author{
Okolonkwo, Benjamin Nnamdi \\ Medical Laboratory Department, Faculty Of Sciences, Rivers State University Of Science And Technology, \\ Nkpolu-Orowurokwo, Port-Harcourt. Rivers State. Nigeria.
}

\begin{abstract}
Paraquat (PQ), a known toxic xenobiotic, has been shown to affect the liver adversely. Its effect on cell membrane integrity has led to the release of membrane enzymes to the extracellular fluid resulting to the increased activity of such enzymes, such as Gamma Glutamyl Transferase (GGT). This study, therefore, has demonstrated that the increased GGT activity as a result of $P Q$ toxicity was reduced as a result of subsequent administration of vitamin $C$ to the animals so treated. The dose and time dependent $P Q$ induced toxicity was found to be significantly lower on test subgroups $\left(B_{2}, C_{2}\right.$ and $\left.D_{2}\right)$ when compared to the test subgroups on $P Q$ insult only $\left(B_{1}, C_{1}\right.$ and $\left.D_{1}\right)$. There were health improvement in the antioxidant treated subgroups, such as feeding habit improved, mortality rate reduced, mobility activity increased, eye colour improved and weightgain increase, when compared to the $P Q$ only treated subgroups. The enzyme activity values of the test groups $(B, C$ and $D)$ were highest at month 3 than months 1 and 2 and, higher at month 2 than month 1, indicating that the increased $P Q$ insult duration resulted to more cellular disruption and increased GGT activity. The control group (A) GGT activity was negligibly altered, maintaining values that were at par even up to the end of the research (Month 3). These findings has demonstrated two things, first is that vitamin $C$ is non-toxic to the animals used and second is that the health index used (GGT) was better appreciated in values of vitamin $C$ treated test subgroups than in the subgroups that were on $P Q$ insult only. It is therefore suggested that vitamin $C$ should be included as supplement, in high-enough dose and duration, in the management of patients under $P Q$ toxicity.
\end{abstract}

Keywords: Paraquat, Vitamin C, Toxicity, Gamma-Glutamyl Transferase, Xenobiotics, Reactive Oxygen Species.

\section{INTRODUCTION}

Paraquat (PQ) is a toxic substance that is involved in several basic cellular processes which can lead to the production of Reactive Oxygen Species (ROS) within a cell. This interruption to the reduction of molecular Oxygen $\left(\mathrm{O}_{2}\right)$ to water on the electron transport chain results in the formation of reactive, partially reduced intermediate, such as the superoxide anion radical $\left(\mathrm{O}_{2}{ }^{-}\right)$, hydrogen peroxide $\left(\mathrm{H}_{2} \mathrm{O}_{2}\right)$ and the hydroxyl radical (HO) that acts as prooxidants.
1) $\mathrm{O}_{2}+\mathrm{e}^{-}-\cdots+\mathrm{O}_{2}^{-}$
2) $\mathrm{O}_{2}^{-}+\mathrm{e}^{-}$
3) $\mathrm{H}_{2} \mathrm{O}_{2}+\mathrm{e}^{-}$
4) $\mathrm{HO}^{-}+\mathrm{e}^{-}$

Figure 1.0: Diagrammatic Representation of Paraquat Redox Reaction

One to five percent of these ROS may escape the electron transport chain and cause damage to cellular components (Punchard, et al. 1996). Furthermore, this process occurs at the expense of cellular reducing equivalents, such as NADPH, which can have consequences for other metabolic processes (Bachur, et al. 1978). Since ROS do have useful functions in cells, such as redox signaling, the function of antioxidant systems is not to remove oxidants entirely, but instead to keep them at an optimum level (Rhee, 2006). However, because ROS are produced in excess as a result of PQ redox-cycling, there activity totally overwhelm the cells resulting in the destruction of cell functionality - such as the starting chemical chain reactions like lipid peroxidation, by oxidizing DNA or proteins (Sies, 1997).

Damage to DNA can cause mutations and possibly cancer, if not reversed by DNA repair mechanisms (Nakabeppu, et al. 2006 and Valko, et al. 2004), while damage to proteins causes enzyme inhibition, denaturation and protein degradation (Standtman, 1992).

Supplementation of antioxidants in diets, drinks, drugs, etc has helped somewhat in limiting the activities of these ROS that are harmful (Vertuani, et al. 2004). The relative importance and interactions between these different antioxidants is a very complex question, with the various metabolites and enzyme systems having 
synergistic and interdependent effect on one another (Chaudiere and Ferreri-Iliou, 1999). Although various antioxidants generally behave synergistically, ascorbic acid can degrade other antioxidants of the phytochemical family anthocyanin (Wild Flavour, Inc. 2009).

Because of vitamin $\mathrm{C}$ ( $\mathrm{L}$-ascorbic acid) nutritional importance, the distribution of ascorbate has been extensively quantified in plants; it has been shown to have essential role in several physiological processes in plants and animals including growth, differentiation and metabolism (Foyer, 1993). Its function as a reductant for many radicals led to its interest in this research.

This study therefore aimed at finding out the antioxidant efficacy of vitamin $\mathrm{C}$ in rats poisoned by $\mathrm{PQ}$ toxicity, using an enzyme - GGT - as an indicator. The research was designed in simulation of environmental pollution from PQ use in farming, eradication of weed in recreational, industrial and transportation facilities. This toxic substance gets in contact to humans through skin contact, inhalation of its fumes, and intake in contaminated food substances and otherwise. It is hoped that this study will shed more light in the management of PQ toxicity using antioxidant - Vitamin C.

\section{MATERIALS}

\section{Materials And Methods}

RATS: 96 male rats, obtained from the animal house of the Department of Pharmacology and Toxicology, College of Health Sciences, University of Port Harcourt, Choba - Rivers State.

SOURCE OF PARAQUAT: The paraquat used was purchased as a liter volume of $20 \% \mathrm{w} / \mathrm{v}$ solution with the trade name Dizmazone, from Dizengoff W. A. Ltd. Sealed in an opaque plastic container. It was kept at room temperature and during use, proper caution were taken to avoid spillage, fire or poisoning.

SOURCE OF VITAMIN C: Four bottles of Mason Natural ${ }^{\circledR}$ pure vitamin C (1000mg) caplet were used for the research.

\section{Method}

A $2 \mathrm{mls} \mathrm{sub} \mathrm{-} \mathrm{lethal} \mathrm{dose} \mathrm{of} \mathrm{the} \mathrm{toxicant,} \mathrm{Paraquat} \mathrm{(PQ)} \mathrm{was} \mathrm{intraperitoneally} \mathrm{(ip)} \mathrm{administered} \mathrm{to} \mathrm{the}$ animals, once a month, over a period of three months (this was in simulation of contamination from polluted feed, water or air), while the control animals received $2 \mathrm{mls}$ of Normal Saline $(0.95 \%)$ likewise.

This study was conducted under four groups $(A-D)$ and eight subgroups $\left(A_{1}, A_{2}, B_{1}, B_{2}, C_{1}, C_{2}, D_{1}\right.$ and $\mathrm{D}_{2}$ ). All the subgroups had 12 animals with $\mathrm{A}_{1}$ and $\mathrm{A}_{2}$ being the control subgroups that received no paraquat.

$A_{2}, B_{2}, C_{2}$ and $D_{2}$ were the subgroups that were made to drink from a water-can containing vitamin $C$ solution (200mg/l) with straw. On emptying, the water-cans were refilled regularly. $A_{1}, B_{1}, C_{1}$ and $D_{1}$ were the subgroups without vitamin $\mathrm{C}$. They were made to drink from water-cans which contained only water.

On monthly intervals, $10 \mathrm{mls}$ blood samples were collected from four animals per subgroup and allowed to clot. The clotted samples were separated using centrifugal force and the sera dispensed into plastic sample containers, labeled accordingly and stored frozen, awaiting GGT enzyme assay later using Kodac Autoanalyser machine.

All through the 3 months study period the animals were fed with pelletized finisher feeds, which contained enough nutrients required for healthy growth and development.

Using the study pattern below, the results were as shown in the tables and figures below.

Table 1: Treatment Pattern For The Groups/Subgroups

\begin{tabular}{|c|c|c|}
\hline GROUP & $\begin{array}{l}\text { SUB- } \\
\text { GROUP }\end{array}$ & METHOD \\
\hline \multirow{2}{*}{\begin{tabular}{lr}
\multicolumn{1}{c}{$\mathbf{A}$} \\
$\begin{array}{l}\text { Control group } \\
\text { given } 0.0 \mathrm{~g} / \mathrm{kg} \text { PQ }\end{array}$ \\
\end{tabular}} & $\mathbf{A}_{1}$ & Subsequently received water and feed \\
\hline & $\overline{A_{2}}$ & Subsequently received Vit. C solution $(200 \mathrm{mg} / \mathrm{l})$. \\
\hline \multirow{2}{*}{\begin{tabular}{l}
\multicolumn{1}{c}{ B } \\
Test group given \\
$0.02 \mathrm{~g} / \mathrm{kg} \mathrm{PQ}$
\end{tabular}} & $\mathbf{B}_{1}$ & Subsequently received water and feed \\
\hline & $\mathbf{B}_{2}$ & Subsequently received Vit. C solution $(200 \mathrm{mg} / \mathrm{l})$ and feed \\
\hline \multirow{2}{*}{\begin{tabular}{l}
\multicolumn{1}{c}{$\mathbf{C}$} \\
Test group given \\
$0.04 \mathrm{~g} / \mathrm{kg} \mathrm{PQ}$
\end{tabular}} & $\mathbf{C}_{1}$ & Subsequently received water and feed, \\
\hline & $\mathbf{C}_{2}$ & Subsequently received Vit. C solution $(200 \mathrm{mg} / \mathrm{l})$ and feed \\
\hline \multirow{2}{*}{\begin{tabular}{l}
\multicolumn{1}{c}{$\mathbf{D}$} \\
Test group given \\
$0.06 \mathrm{~g} / \mathrm{kg} \mathrm{PQ}$
\end{tabular}} & $\mathbf{D}_{1}$ & Subsequently received water and feed \\
\hline & $\mathbf{D}_{2}$ & Subsequently received Vit. C solution $(200 \mathrm{mg} / \mathrm{l})$ and feed \\
\hline
\end{tabular}

Procedure for the enzyme (GGT) estimation, were based on the principles of the colorimetric method by Szasz (1969). The enzymatic activities of different subgroups were as shown below. 
Table 2: Values Of The Enzyme (Ggt) Activities Within The 3 Months

\begin{tabular}{|c|c|c|c|c|c|}
\hline GROUP & $\begin{array}{l}\text { SUB } \\
\text { GRP }\end{array}$ & $\begin{array}{l}\text { RAT } \\
\text { NO }\end{array}$ & $\begin{array}{l}\text { MONTH } 1 \\
\text { (IU/L) }\end{array}$ & $\begin{array}{l}\text { MONTH } 2 \\
\text { (IU/L) }\end{array}$ & $\begin{array}{l}\text { MONTH } 3 \\
\text { (IU/L) }\end{array}$ \\
\hline \multirow{2}{*}{$\begin{array}{l}A \\
(0 \mathrm{~g} / \mathrm{kg})\end{array}$} & A1 & 4 & $13.6 \pm 3.8$ & $13.3 \pm 1.7$ & $12.8 \pm 0.8$ \\
\hline & A2 & 4 & $12.2 \pm 2.6$ & $13.5 \pm 3.0$ & $11.6 \pm 1.8$ \\
\hline \multirow{2}{*}{$\begin{array}{l}\text { B } \\
(0.02 \mathrm{~g} / \mathrm{kg})\end{array}$} & B1 & 4 & $32.0 \pm 5.6$ & $63.0 \pm 3.9$ & $87.0 \pm 13.0$ \\
\hline & B2 & 4 & $22.3 \pm 3.3$ & $36.9 \pm 3.0$ & $50.0 \pm 2.1$ \\
\hline \multirow{2}{*}{$\begin{array}{l}\mathrm{C} \\
(0.04 \mathrm{~g} / \mathrm{kg})\end{array}$} & C1 & 4 & $42.7 \pm 9.9$ & $76.2 \pm 3.0$ & $128.5 \pm 8.5$ \\
\hline & $\mathrm{C2}$ & 4 & $26.3 \pm 5.5$ & $35.1 \pm 2.2$ & $56.5 \pm 3.5$ \\
\hline \multirow{2}{*}{$\begin{array}{l}\text { D } \\
(0.06 \mathrm{~g} / \mathrm{kg})\end{array}$} & D1 & 4 & $65.0 \pm 3.7$ & $99.0 \pm 6.0$ & $170.0 \pm 6.4$ \\
\hline & D2 & 4 & $35.5 \pm 4.7$ & $76.0 \pm 2.3$ & $125.0 \pm 2.4$ \\
\hline
\end{tabular}

MEAN \pm SEM; WHERE $n=4$

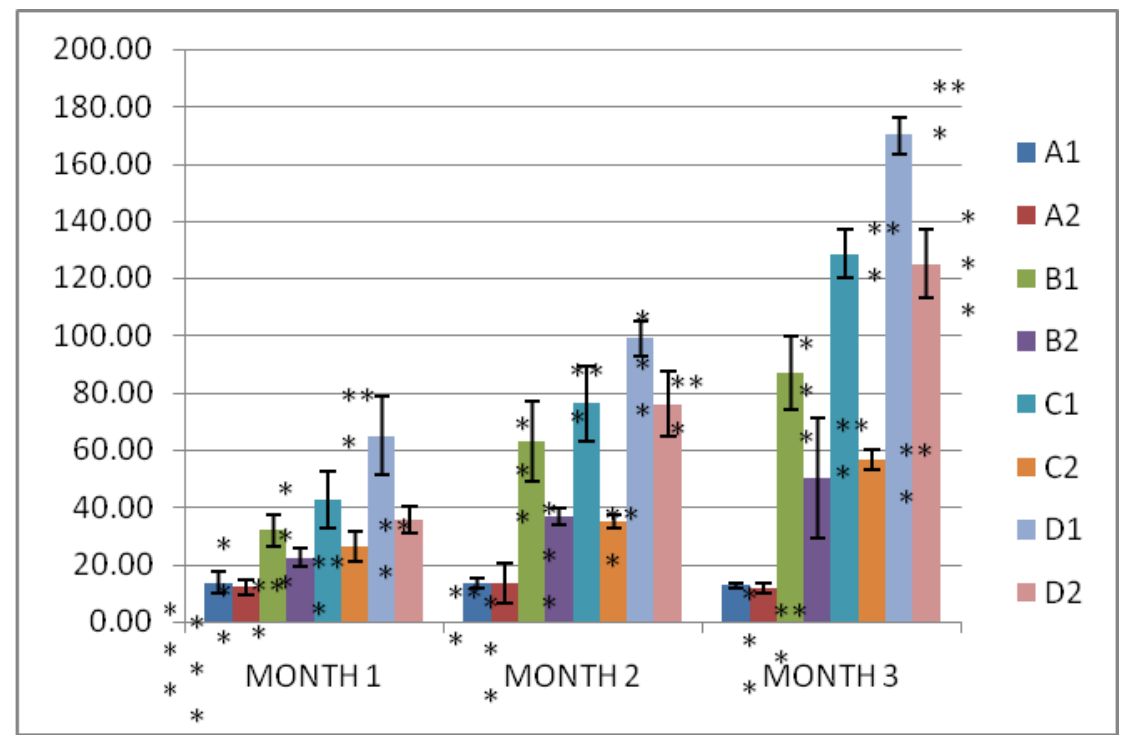

IV

DISCUSSION

Paraquat has been shown to be highly hepatotoxic (Dede, et al. 2007) and the mechanism of its toxicity on the liver cells has been extensively reported by (Bachur, et al. 1978).

The liver enzyme GGT, in this study, had values that were highly significant $(\mathrm{P} \leq 0.001)$ both within and between groups/subgroups (Table 2.0 and Fig. 1.0) and these changes were all dose and time dependent when compared to the control subgroups $\left(\mathrm{A}_{1}\right.$ and $\left.\mathrm{A}_{2}\right)$. The increased level of GGT enzyme activities where lower in the subgroups that received vitamin $C\left(B_{2}, C_{2}\right.$ and $\left.D_{2}\right)$ as compared to the subgroups on PQ insult only $\left(B_{1}, C_{1}\right.$ and $\left.D_{1}\right)$. Signifying that the introduction of vitamin $C$ to the animals in the vitamin $C$ treated subgroups $\left(B_{2}, C_{2}\right.$ and $\left.D_{2}\right)$ facilitated the reduction in the activities of the enzyme even when the dose of the toxicant (PQ) was overwhelming the cellular metabolism of the animals. These findings were corroborated in the report of Atroshi, et al. 1997, where they mentioned that, the elevated liver enzyme activity as a result of PQ insult at different doses and routes were ameliorated by the subsequent administration of antioxidants which included vitamin $\mathrm{C}$ and Alphatocopherol, either alone or in combination. Balaruddin, et al. 2011 in their study on inhalation and dermal exposure to 2,4 - D and paraquat among Malaysian Paddy Farmers observed that "Long term spraying activities were positively correlated with increasing levels of the GGT liver enzyme", gave credence to the findings in this study. Also the results were supported by the results in a short-term study of "The effect of PQ on the activity of some Enzyme in different Tissues of Mice (Mus musculus - Swiss albino)", which revealed that there was significant increase in the level of liver enzyme - GGT - activities (Dere and Polat, 2001).

The control subgroups from month 1 to month 3 consistently showed that vitamin $\mathrm{C}$ administration on subgroup $\mathrm{A}_{2}$ had no adverse effect as the enzyme activity remained almost at the same value range (Fig. 1). But the test groups (B, C and D), continued to show results that where directly proportional to the dose and duration of treatments given to the animals. 


\section{CONCLUSION}

It was evident from this study that vitamin $\mathrm{C}$ ameliorated the toxicity effect of $\mathrm{PQ}$ in the rats, but that the concentration of vitamin $\mathrm{C}$ given should be made to be directly equivalent in proportion to the dose and duration of the toxicant given.

Therefore, the suggestion that vitamin $\mathrm{C}$ should be an added medicament in the treatment of acute or chronic PQ toxicity should be internationally recommended and that it should be continued on the patient even when the clinical signs has reduced, because of its role in repairing cells and tissues.

\section{References}

[1]. Atroshi, F: Rizzo, A; Biese, I; Veijalainen, P; Antila, E. and Westermarck, T. (1997). The protective effect of pretreatment with coenzyme Q10 and alpha tocopherol on T-2 toxin- induced DNA damage in mouse livers. Molecular aspect Medicine (United Kingdom), 18/SUPPL. (S255-S258).

[2]. Bachur, N. R., S. L. Gordon and M. V. Gee 1978. A general mechanism for microsomal activation of quinine anticancer agents to free radicals. Cancer Res. 38: 1745 - 1750.

[3]. Baharuddin, M. R.; Sahid, I. B.; Noor, M. A.; Sulaiman, N. and Othman, F. (2011). A study on Inhalation and Dermal Exposure to 2, 4-D and Paraquat among Malaysian Paddy Farmers. Pesticide Risk Assessment. J. Environmental Sci. Health B. 46(7): 600 607.

[4]. Chaudiere, J. and Ferrari-Iliou, R. (1999). “Intracellular antioxidants: from chemical to biochemical mechanisms”. Food Chem. Toxicol. 37(9-10): $949-962$.

[5]. Dede, E.B; Okolonkwo, B.N.; Ngokere, A.A. (2007). Toxicological effect of paraquat on the histology of the stomach, small Intestine and testis of male albino rats (Rattus rattus). Port Harcourt Medial Journal, 2: 51- 55.

[6]. Dere, E. and Polat, F (2001). The Effect of Paraquat on the Activity of some Enzyme in Different Tissues of Mice (Mus musculus Swiss albino). Turk J. Biol. 25: 323 - 332.

[7]. Foyer, c. (1993). Ascorbic acid. In: Antioxidant in higher plants. R.G. Alscher and J.L. Hess (eds). CRC press, Boca Raton, pp.3158.

[8]. Nakabeppu, Y.; Sakumi, K.; Sakamoto, K.; Tsuchimoto, D.; Tsuzuki, T.; Nakatsu, Y. (2006). "Mutagenesis and Carcinogenesis caused by the oxidation of nucleic acids". Biol. Chem., 387(4): $373-379$.

[9]. Punchard, N.A. and Kelly, F.J.( Eds.) (1996). Free Radicals: A practical Approach. Oxford: 1RL press.

[10]. Rhee, S.G. (2006). "Cell signaling. H2O2, a necessary evil for cell signaling”. Science (journal), $312(5782)$ : 1882 -1883.

[11]. Sies, H. (1997). "Oxidative stress: Oxidants and Antioxidants” (PDF). Exp. Physiol., 82(2):291-295.

[12]. Stadtman, E. (1992). "protein oxidation and aging”. Science, 257(5074): 1220 - 1224.

[13]. Szasz, G. (1969). The quantitative in-vitro determination of Gamma Glutamyl Transferase in serum or plasma. Clin. Chem. 22: 124 $-136$.

[14]. Valko, M.; Izakovic, M.; Mazur, M.; Rhodes, C.; Telser, J. (2004). "Role of oxygen radicals in DNA damage and Cancer incidence”. Mol. Cell Biochem., 266(1 - 2): $37-56$.

[15]. Vertuani, S.; Angusti, A.; Manfredini, S. (2004). "The antioxidants and pro-antioxidants notwork: an overview". Curr. Pharm. Des., 10(14): $1677-1694$.

[16]. Wild Flavors, Inc. (2009). “Anthocyanins”. http://www.wildflavors.com/? Page id. 